\title{
Securitization and the Political: Contributions from Hannah Arendt
}

\author{
Securitização e a Política: \\ Contribuiç̧ões de Hannah Arendt
}

Rev. Bra. Est. Def. v. 3, n 1, jan./jun. 2016, p. 23-51

ISSN 2358-3932

\section{BÁRBARA MOTTA \\ CAUÊ PIMENTEL}

\section{INTRODUCTION}

Since its foundation, Securitization Theory (ST) has spurred an extensive body of research, both empirical and theoretical. In the last few years, there has been an increasing debate over the concept of the political implicit in the theory. The origins of this debate are related to the problem of "exception" that the theory presents: by conceptualizing the securitization move as a turning point when an audience accepts exceptional measures to counter a security problem, the theory implicitly calls for a definition of what would be the realm of "normal politics" and the inherent political consequences of "exceptionalism". These specific issues are polarized on the concepts of securitization and desecuritization which capture the "rhetorical struggle" between the realm of normal politics and the exception (Tjalve 2011).

In this paper, our aim is to develop an alternative conceptualization to the dominant Schmittian approach by making an intellectual exercise using the works and concepts of Hannah Arendt. The usefulness of Hannah Arendt has been cited by some authors in the ST field like Aradau (2014), Jutila (2006), Floyd (2010) and even the 'founders' of the Copenhagen School Ole Wæver (2004, 2011) and Barry Buzan et al. (1998). Despite these mentions, the contributions from Hannah Arendt still remain little explored and thus call for further development in the current bibliography. We seek to understand how securitization theory has a so-called "Arendtian concept of politics" (Waever 2011,470). We will take an exploratory journey through

Bárbara Motta - Doutoranda e Mestre em Relações Internacionais pelo Programa de Pós-Graduação San Tiago Dantas (UNESP/ UNICAMP/ PUC-SP). E-mail: barbaravmotta@hotmail.com.

Cauê Pimentel - Doutorando em Ciência Política pela Universidade de São Paulo (DCP-USP). E-mail: cauerpimentel@hotmail.com. 
the works of Arendt considering the most acute problems and challenges in the securitization debate. Thus, we will offer one of the many possibilities that the complex thought of Hannah Arendt can present to the theory. ${ }^{1}$

Our main argument is that Arendt's political concept can cope with the (de)securitization process as a whole, thus enhancing the explanatory strength of the theory. In other words, we believe that the complexity of Hannah Arendt's concept of action and speech (the basic elements of the political) serves better the theory than the decisionist, authoritarian, and unilateral concept that comes from Schmitt: whereas the latter is much more akin to an illocutionary speech-act, the concept deriving form Arendt is closer to the perlocutionary speech-act that conforms the sociological vocation of the theory, maintaining a window of emancipation out of the "security trap" of modern politics. ${ }^{2}$ Arendt's thought, thus, can have some impact in redefining the normative core of the theory while presenting some insights about the concepts of action, speech, judgment, and audience.

This article is organized in three sections. First, we will retake the debate on the political starting by a critic against Schmitt's conceptualization, showing why his concepts fail to solve the most pungent problems in the ST; In the second section we will present the concept of the political based on Hannah Arendt and her concept of action, speech and judgment and how they are related to the (de)securitization process; in the third part we will work on her concept of audience, present in her essay Lying in Politics, and on how we can correlate it to actual debates on ST.

\section{SCHMITT AND (DE)SECURITIZATION - A PROBLEMATIC CONCEPTUALIZATION}

When Securitization Theory was first coined, it used the idea of "exceptional measures" but without any reference to Schmitt's concept of the political. Indeed, only one negative mention of Schmitt can be found in the whole text of the 'Framework' book (1998, 143) saying that "politics cannot be reduced to the friend-enemy distinction" as Schmitt envisioned. Wæver (2004) later admitted that the concept was not formulated having Schmitt's work in mind. Schmitt entered the "jargon" of the theory afterwards, by the hands of some authors like Williams (2003), Huysmans ${ }^{3}$ (1999, 2006, 2008) and Behnke (2006) who saw the securitization move rooted in an Schmittian understanding of the political order. ${ }^{4}$ Since then, the idea of a "Schmittian" concept of the political gained popularity within the specific bibliography of Securitization Theory in two broad aspects.

First, Schmitt was used specially to tackle the problem of the thin conceptualization of politics that lies at the core of ST. For Schmitt, the po- 
litical appears in its purest form when the sovereign imposes the distinction between friends and enemies and thus he has the power to suspend the normal rules and procedures of the political game. Schmitt argues, therefore, that there is an essence in the political that may be reduced to the dichotomy of amity/enmity. According to Schmitt,

A definition of the political can be obtained only by discovering and defining the specifically political categories. In contrast to the various relatively independent endeavors of human thought and action, particularly the moral, aesthetic, and economic, the political has its own criteria which express themselves in a characteristic way. (...) The specific political distinction to which political actions and motives can be reduced is that between friend and enemy $(\ldots)$ The distinction of friend and enemy denotes the utmost degree of intensity of a union or separation, of an association or dissociation (2007, 25-26).

It is not difficult to understand why some authors (Williams 2003) have made the link between this Schmittian mode of politics and the securitization process. First, to both Schmitt's concept of the political and ST the inner nature of an issue (if it is good or bad, real or not real) is not relevant for the analysis. Whilst Schmitt focuses on the intensity of a relationship between two or more actors to create the antagonism of amity/enmity - it is irrelevant if the political enemy is "morally evil or aesthetically ugly", he only has to be "existentially something different and alien" (Schmitt 2007, 27) -, ST disregard if one issue is truly a real threat or not: what matters is the performative effect of identifying an object as a threat. In this sense, the security problem is mediated by the speech-act, "by labeling it as security, an agent claims a need for and a right to treat it by extraordinary means" (Buzan et al. 1998, 26). In this sense, exception means that the audience loses something in exchange for more security: their freedom, their ability to participate in politics, part of their rights etc.. ${ }^{5}$

Schmitt's conception was later contested by Wæver and Greenwood who claimed that Schmitt's idea of exception is different than the concept found in ST. They say:

Carl Schimitt's infamous conception of politics focuses on a general situation of exception where the entire society in re-grounded. Securitization relates to limited exceptions: within an order that is not generally challenged, arguments are made for exception in a specific field. Therefore, the theory is distinct from Schmitt's (2013, 501).

Hence, Schmitt's concept became not the solution for the theory, but a liability and an obscure point with important normative impact. That 
is because for ST "exceptionalism is seen as a way to end normal politics. In Schmitt, politics is only realized in the exception" (Gad, Petersen 2011,320). As Bigo (2002) asserted, the Schmittian approach to security issues reifies the "essence" of security by validating the opinions of security professionals/decision-makers who believe that acting "beyond the law" is necessary and even desirable in order to achieve state's security goals. ${ }^{6}$ For all these reasons, turning to Schmitt only strengthens the "security trap" that the theory purportedly tried to avoid. Plus, it makes conceptually impossible to understand situations in which the employment of emergency measures is not necessary to convince an audience about existential threats (Roe $2008,621)^{7}$ or to comprehend the complexity of modern politics where, according to Arendt's philosophy, exceptional measures and normal politics can function inside a democratic order without necessarily falling into the realm of violent exceptionalism (Williams 2014), thus working in subtler juridical-political artifices that allow for the violation of rights or extensive surveillance in the name of the raison d'etat and national security. ${ }^{8}$

The second way in which ST has been read through the lens of Schmitt is how the enemy/amity distinction is a function limited to the sovereign - read as the securitizing actor that performs an illocutionary move towards an audience that accepts or rejects that utterance passively. Without a dense conceptualization of the audience, the securitization move turns out to be a self-referential practice - and here, the securitization theory loses its fundamental social character. ${ }^{9}$ Balzacq (2011) summed up the consequences of adopting an illocutionary perspective in securitization theory rather than a perlocutionary one. ${ }^{10}$ The former locates the speech act's utterance and the securitizing actor in a position of precedence as such that the securitizing actor alone, like the Schmittian sovereign, is the only one capable to define and decide over the exception. ${ }^{11}$ The role of the audience(s), the context, and the positions of power are minimized in a 'one-way street' securitizing movement where the audience only gives (or not) its approval. The context and the positions of power become, therefore, static elements helping legitimate the securitization only by providing it some felicity conditions (as Austin puts it). They are no longer equally bound co-participants in a complex social web of bargain and dispute, instead, a hierarchical disposition instantly reorganizes actors and audiences, empowered individuals and disempowered ones.

Consequently, with a Schmittian approach, securitization theory strays from the "realm of debate and deliberation" (an Arendtian conception of politics) and places itself, as Roe (2012) precisely summarizes it, in the realm of "speed and silence". The theory becomes merely a technique of government based on the use of force, helping its critics to essentialize 
securitization as a necessarily negative movement, inasmuch as it contributes to the complete abandonment or at least the disruption of democratic clear and accountable mode of politics. ${ }^{12}$ As Huysmans (2008) correctly asserts, by rending exceptionalism as the central concept of the political, Schmitt eliminates one of the fundamental categories of democratic politics, providing a simplified version of politics.

By reducing the political to a dichotomy of two antagonist forces (just like the beautiful and the ugly, the good and the bad in his words) Schmitt reduces the political to one single act: the act of distinguishing between these two aggregate figures. In the jargon of securitization theory, the Schmittian concept of the political demands a decisionist and foundational illocutionary act, which resembles a command. ${ }^{13}$

While Wæver (apud Roe, 7) encourages us to see "securitization as what is done in the (collective) act" - how can we see securitization as a social possibility in the everyday political life when the Schmittian interpretation of politics removes the sociological character of the theory? Schmitt presents a very narrow concept of the political which is mainly essentialist and excludent ${ }^{14}$ and hence places the securitization theory in a zero-sum framework. As Hannah Arendt $(1961,240)$ pointed out in one of her rare citations of Schmitt, "[ he] recognizes clearly that the root of Sovereignty is the will: Sovereign is who wills and commands".

Ole Wæver clearly remarked that securitization theory should not be interpreted through the lens of a Schmittian concept of politics. In his words, "[securitization] theory has a Schmittian concept of security and an Arendtian concept of politics ${ }^{15}$ " $(2011,470)$. His article, however, does not develop this idea much further. The main problem with the Schmittian approach is the ontological obstacle it posits to the issue of desecuritization. For the Copenhagen School, desecuritization is a fundamental concept (Wæver 1998; Hansen 2012). The desecuritization process consists of removing a matter of the emergency status and transferring it to the ordinary procedures of bargaining within the political sphere. ${ }^{16}$

However, the desecuritization movement cannot be evaluated under the same basis as the securitization theory once was built around. Unlike securitization, the desecuritization is not a process conducted in two stages in which a speech-act presents an issue as non-threatening and suddenly the actors have the capacity to no longer perceive it as a security matter. In other words, desecuritization is not a rigid process that can be followed in order to "unmake" the securitization move. Instead, it is a complex social process engaged in a continuous struggle about the significance of events and where individuals and collectivities are constantly judging the facts of the political life. If we follow Schmitt's concept of 
the political, then there is no room for desecuritization, because erasing enemy/amity distinctions is equivalent to suppress the political. At this point, the Schmittian contribution is no longer capable of explaining Securitization Theory. In other words, in a Schmittian concept of politics, securitization would be the moment in which the sovereign decides; in an Arendtian description of politics, desecuritization would be the moment when audiences react through judgment, or, as Vuori $(2011,6)$ points, it would be a process by "which security issues lose their 'securityness' and are thereby no longer restrictive by nature, as there is no need to repel threats, but become 'open' in an Arendtian sense'.

The historical context in which Schmitt wrote his masterpiece The Concept of the Political cannot be forgotten as exceptionalism was not seen as an aberration but as proper replacement for failing liberal regimes. Nevertheless, the question today should be radically different. Do we live in Schmittian world? Or even more important: do we want to live in a Schmittian world? Citing Roe (2012, 12), "what kind of politics do we want?” That is why we turn to Arendt's work.

\section{A JOURNEY WITH ARENDT: EXPLORING CONCEPTS FOR THEORIZING ST}

Like said before in this article, some authors cited Arendt as a potential theoretical inspiration for ST. However, this has not been developed systematically in the theory, leaving gaps about how and why Arendt can be helpful. ${ }^{17}$ Instead, Arendt has been what we call a "silent presence" in securitization studies. We make this statement based on passages by Buzan ${ }^{18}$ and Waever in which they purportedly alleged that ST had an Arendtian inspiration, but without clarifying it much further.

In his article Politics, Security, Theory, Ole Wæver says that his "general [concept of] politics is inspired by Hannah Arendt, because that which is narrowed down and constrained in the Schmittian security moment is necessarily a wider and different kind of politics". Rita Floyd summarizes how Arendt influenced Wæver:

Inspired by Hannah Arendt's writings Wæver believes that politics should be done consensually and through dialogue and deliberation, as opposed to politics being a top-down process. Consequently, for him security policy too is viewed as an intersubjective process and is not decided by an individual actor or body (Floyd 2010, 50).

She goes on citing how Wæver conceived politics in an Arendtian fashion, bearing in mind the boundless character of our actions, the persuasive 
function of the speech-act between agents, and the "unconscious of language' where the word travels independently of the logical structures one wanted to contain in it" (Floyd 2010, 27):

[I]n order to avoid simply moving from objective to subjective - it should be stressed that since securitization is never (in contrast to Schmitt) decided by one sovereign subject but in a constellation of decisions it is ultimately inter-subjective (and truly political in an Arendtian sense) (Wæver 2014 apud Floyd 2010, 50)

Wæver $(2014,27)$ finally states that "Securitization theory was built from the start on speech act theory, because it is an operational method that can be designed to protect politics in Arendt's sense ${ }^{19}$ ". This statement is particular interesting because Arendt's thought is usually referred by her detractors as too idyllic or utopian, an unrealizable venture in modern politics. Balzacq (2014), for instance, sustains Arendt's vision of the political as a "purified" version of politics, especially when she puts violence as an anti-political element. ${ }^{20}$ But that does not mean her thoughts were disconnected from world affairs. Quite the opposite: no author matches the interest and engagement that Hannah Arendt devoted to the problems of violence and politics in the 20th century. ${ }^{21}$ As Arendt herself always answered her critics, she was not a philosopher detached from the world problems: instead, she always emphasized the difference between the philosophical tradition she drew from and her political theory focused on the concepts that many other authors before her had naturalized and instrumentalized (especially the idea of violence and freedom found in Hobbes, Locke or Marx and most of the modern political science). By separating the vita activa and the vita comtemplativa, Arendt tackles the tension between politics and philosophy that for her started with Plato and plagued political thought throughout the XX century. Her extent works on Totalitarianism and the compendium of the Crises of the Republic, certainly are "practical" works where Arendt showed her acute perception on how politics could contribute to unveil some of the most important events of her time.

As Mrovlje (2014) asserts, Arendt's political theorizing is much more a narrative approach to the political phenomena than a strict method of research and theorizing, with clear-cut procedures and concepts. What seems an unintelligible way to theorize is actually a "commitment to illuminating and making sense of the plural, unpredictable and changing world reality." In the following section we will try to show some of the main concepts of her theory and try to relate them to the main concerns of contemporary debates of the securitization field. 


\section{Speech, Action and Judgement}

What is the core concept of the political in Arendt's thought? Unlike Schmitt, Arendt never wrote a general theory of the political or a book where she summarizes her multifaceted writings and opinions. The closest she gets to a "general theory" of the political can be found in The Human Condition (1958), which she described as her prolegomena. Therefore, this shall be the starting point if we are looking to grasp the "essence" of her concept.

In The Human Condition, Arendt sets the three activities that define the human existence: labor (the biological life of man), work (the world of objects and human artifice), ${ }^{22}$ and action which "corresponds to the human condition of plurality" that is the condition "of all political life" (Arendt 1959, 7). Together, they form the vita activa, the very condition of all human existence. For Arendt, actions are the fundamental activity of the political because it is what constitutes identities between men. As she asserts, "in acting and speaking, men show who they are, reveal their unique personal identities and thus make their appearance in the human world" (1959, 179). Therefore, there is a performative character in Arendt's concept of action (Stritzel 2007), which emphasizes that political action depends on the existence of others, on the presence of audiences to be a meaningful action. "Without the presence and acknowledgment of others, action would cease to be a meaningful activity. Action, to the extent that it requires appearing in public" (D'Entrèves 2014). As Guzzini (2011) remarked, this performative characteristic is intrinsically a constructivist approach to the social reality.

The links to the Copenhagen School foundations are thus vivid. To the securitization theory the "speech act in interesting exactly because it holds the insurrecting potential to break the ordinary, to establish meaning that is not already within the context - it reworks or produces a context by the performative success of the act" (Buzan et al. 1998, 46). Throughout her texts, Arendt continuously associates action with speech. In The Human Condition (Arendt 1959, 179) she states that "speechless action would no longer be action because there would no longer be an actor, and the actor, the doer of deeds, is possible only if he is at the same time the speaker of words", which means that "no other human performance requires speech to the same extent as action" and, therefore, the political life. There is some debate whether action and speech are actually interchangeable concepts in Arendt's thought (thus having a common ontological identity); nevertheless, both are part of an indissociable relation for her conception of politics. ${ }^{23}$ For Arendt, action entails speech as humans are only able to articulate and coordinate actions by the means of language, while speech entails action, in the sense that 
speech itself is a form of performative speech-act that equals the political action (D'Entrèves 1994, 71).

Speech has three fundamental characteristics for Arendt: it connects actors and spectators, thus creating an audience; speech articulates the meaning of life (and actions) for a community of shared thoughts; and finally, speech is an extension of reason and judging, thus forming human motivation and behavior (Voice 2014). As Wæver remarked "the political conception of securitization theory is inspired by Arendt, implemented through speech act theory" (2014, 27).

Differently from Schmitt, who classifies the political as the distinctive action of separating enemies and friends, Arendt does not qualify the content of action. To complement the concept of action and the political, Arendt later developed the concept of judgment. For her, while action is the central category of political life, judgement is the faculty that responds to and evaluate actions (D'Entréves 1994). Unfortunately, Arendt never fully developed her Theory of Judgment: the topic would have been the main issue of her book The Life of the Mind, which she was composing when she died in 1975. What were left about the Theory of Judgment are some fragments that are distributed among some of her articles in Between Past and Future (1961); her postscript Lectures on Kant's Political Philosophy (1992) and a small article entitled Thinking and Moral Considerations: A Lecture (1971). From these three fragmented sources we can extract her concept of judgment which can be synthesized as the "political ability [that] enables individuals to orient themselves in the public realm and to judge the phenomena that are disclosed within it" (D'Entrèves 2014).

What is interesting in her concept of judging is how the performance of judgment is divided into two models or phases: "one based on the standpoint of the actor, one based on the standpoint of the spectator, which are somewhat at odds with each other" (D'Entrèves 1994, 103). As Beiner states (Arendt 1992, 92), one acts with others, whilst one judges by oneself weighing the possible judgments of an imagined other (and not the "actual judgments of real interlocutors"). For her, judgment is an indispensable element that sustains shared senses of reality and truthfulness (Hayden 2014).

Judging is a concept which has affinities to the process of desecuritization: in judgement there is the potential of "emancipation" that many critical theorists emphasized on their works and writing. Through judgement individuals and collectivities could create conscience and hold a critical stance in front of political dilemmas, like security. Judging, thus, is a concept of the critical toolbox that may allow desecuritization to be successful or to at least create resistance against a securitization move. Judging and 
critically thinking would be, therefore, the first step towards desecuritization. The faculty of judging operates especially on those situations - like an unexpected aggression - when traditional standards of interpretation collapse and the situation calls for new, quick responses from individuals and institutions (D'Entrèves 1994).

While acknowledging that judging is a faculty of the self, Arendt does not fall into a pure liberal idea of the idealized man of reason that only by rationalizing in his loneness is able to illuminate the world with the sheer truth. Judgment, she argues, "is not a prerogative of the few but an ever-present faculty in everybody; by the same token, inability to think is not a failing of the many who lack brain power, but an ever-present possibility for everybody" (Arendt 1971, 445). For Arendt, the biggest (and realest) example of how judgment can fail is the experience of totalitarianism (Arendt 1973). Once again, Arendt takes her abstract conceptualization of judgment and confronts it with the scenario of "real politics": the capacity of thinking does not mean that human agents will make "correct" judgments. Instead, she affirms that judgement is usually formed by prejudices that are the background opinion that form the ordinary discourse and context of our daily lives ${ }^{24}$ (Hayden 2014). That is possible because discourse, for Arendt, is a matter of persuasion that appeals to reason just as it appeals to emotions and sensations, including fear and insecurity (Teles 2014, 99). In this sense, audiences may play an active role in securitizing a referent object instead of being passive or just "preys" of a securitization move, since their opinions ${ }^{25}$ and "emotions" must be taking in account.

Most importantly, while for Schmitt "judging" who is the enemy and who is the friend is a faculty restricted to the sovereign, for Arendt, judgment is an activity that conforms the human condition. If we read securitization through this concept, then the process of securitizing cannot be a one-way road paved by one actor, but the degree of attachment of a speech-act can only be measured by how the audience judges one action. Thus, we should change the start of the analysis of securitization by first asking to whom a securitization move is addressed (Wilkinson 2005) and not only whether the audience accepts or not that discourse, but how the discourse is judged by multiple audiences. The two phases put by Arendt (from the standpoint of actor/audience) is much alike what Roe $(2008,615)$ translated into a "stage of identification" and a "stage of mobilization" in the process of securitization, highlighting that audiences are active agents that can actually provide judgments about the "securityness" of an issue. Like Buzan et al. (1998, 31) alerted "security (as with all politics) ultimately rests neither with the objects nor with the subjects but among the subjects". 
From the perspective of the analyst, developing the relation between the theory of judgment and the securitization theory can be of great value to enhance empirical researches that do not necessarily start from the approach of securitization, but rather by retracing the strategies of desecuritizing agents. There is, however, a gap of temporality which differentiates securitization from desecuritization. In all securitization movements and especially in the macrosecuritization move (Buzan 2009), as the securitization of terrorism made by the US after $9 / 11$, it takes time for divergent voices to be heard and echo through society. The images of the falling Twin Towers are powerful events that, read by an articulation of a security speech, led to the Global War on Terrorism. Even after 13 years after the attack on the Twin Towers, the discourse against terrorism is incredibly strong and constantly updated by other terrorist events that audiences (especially Western audiences) still see as an existential threat. To use an Arendtian concept, this rearticulation of the past is still very present today, and it is even facilitated by the recurrent images and powerful emotions that terrorist attacks create on audiences through the visual representations of mass media ${ }^{26}$ (Hansen 2008) Nonetheless, concurrently, there have been a growing number of voices against these securitization attempts and not all securitization moves worked equally or were successful (Salter 2011). As one can easily perceive, only a few have triumphed: those discourses are entangled on a continuous struggle over the significance of events and the definition of political priorities and public policies. Applying the theory of judgment to (de)securitizing movements would also allow researchers to evaluate why and how some rule breaking policies to address the securitization of terrorism were accepted and some were not. As Bright puts it,

Empirical research has shown that a security situation can be generally accepted, yet individual rule breaking procedures which purport to tackle it still rejected. It would be difficult to claim, for example, that the threat of terrorism has not been securitized in many Western countries following the attacks of $9 / 11$ (if it was not already). Yet a huge variety of different policies have been proposed to tackle this threat: not all have been accepted. Buzan and Wæver themselves have defined terrorism as a 'macro-securitization', a security threat which can connect to a huge range of more specific policies. But this raises the question of how this connection occurs, and how some policies succeed whilst others fail. $(2012,6)$

One of the questions that are currently on the research agenda of ST is the discussion about when and how a securitization move ends and even if 
one can make that distinction of pointing out the beginning and the finish line of a securitization process. Wæver $(2014,27)$ argued that "politics takes place among people [...] because power only emerges when people act together; it basically consists of action directed to and dependent on the reaction of others not doing things directly". This "place" of politics in the "in-between" of people comes directly from Arendt. For her, actions are "boundless" which means that the consequences of a speech are "inherently unpredictable". The speaker/actor does not have control of his own speech. She asserts that:

"Consequences are boundless, because action, though it may proceed from nowhere, so to speak, acts into a medium where every reaction becomes a chain reaction and where every process is the cause of new process. [...] Reaction becomes a chain reaction and where every process is the cause of new process. [...] Thus action and reaction among men never move in a close circle and can never be reliably confined to two partners" (Arendt 1958, 190)

This perspective on speech and action challenges the linear and stepwise dynamic of security construction that starts out with an actor (usually the state or the establishment) who construct a threat narrative (Wilkinson 2011,94). Jutila (2006, 180) completes this idea by stating that in an Arendtian vocabulary, "one can make an initiative, but such an initiative is always made on the condition of plurality and therefore almost never achieves its purpose" or at least in the way that the original agent desired. If we follow Arendt's concept, securitization can start at any moment, actually it is a continuum in the public sphere and thus, really hard to locate the precise microsociological place where it happens (Salter 2008). This has profound impact on the theory: the notion of power conceived in securitization becomes consistently more fluid. Similarly to a room with multiple mirrors and a flash of light, power is produced and reproduced in unlimited and infinite directions - power (in combination with speech) turns into a denser variable to the securitization process as it can spin throughout securitizing actors, audiences and given contexts. Rather than perceive securitization as a 'one way street' movement between the securitizing actor and the audience, the image we had with Schmitt's concept of the political, Arendt's contribution allows us to construct the securitization movement as a web of interactions where the same agent can play different roles (as a (de)securitizing actor or an audience) at the same securitization process. Just as actions, that for Arendt are boundless, the securitization movement also becomes boundless, working much like a network of nodes (epistemic communities, decision-makers, bureaucratics, media, civil society associations) that can be depicted as social fields in a Bourdieu's conceptualiza- 
tion of how agents behave and construct hierarchical positions that may vary contextually (Balzacq 2011). Thus, securitization should be studied as a process unfolding over time, involving continuous, contested meaning-making throughout different social fields.

For Arendt, the capacity to judge is an ideal-type political ability that depends on the capacity of individuals to express their opinions and have impartial information on the public realm. She also recognizes that the tragedy of modern society and contemporary politics is how public affairs are usually secluded in the mist of secrecy or arcana imperii- "the mysteries of government". As she realistically acknowledges, "Truthfulness has never been counted among the political virtues and lies have always been regarded as justifiable tools in political dealings" The major point here is that, even if Hannah Arendt political concept and normative propositions may seem hardly pragmatic or achievable, she actually has a very pungent argument about the problem of modern politics and how the main challenge of our times is precisely to retake their citizenship of and to actively participate and exert judgement about political events. This normative dimension can be implicitly noticed in the foundational commitment of securitization theory that had as its primary commitment the goal to remove security problems from the secluded realm of the military and diplomatic "high politics" - the arcana imperii of modern bureaucracy - and to reintroduce it as political problems that actually need to be debated and deliberated in the 'public sphere'. As the first paragraph of the New Framewok for Analysis (1998, 1) states: "[securitization theory] approach is based on the work of those who for well over a decade have sought to question the primacy of the military element and the state in the conceptualization of security". The difficult task of ST is to define who says what, who influences who, and what is the multiple meanings threats and risks in a world that the word security has become an echo in-between the multitudes of people.

\section{Audiences}

In securitization theory, to be successful, the securitization move must be accepted by the audience. This is a main point of the theory, but it has been under-theorized in its foundational texts. Léonard and Kaunert (2011) showed how the role of audiences is vague and contradictory in the theory, especially the absence of a clearer definition of what constitutes the audience and how it accepts (or rather how it manifests its acceptance) of the securitization discourse.

Audiences can assume multiple forms depending on the context and on the empirical analysis of each research. ${ }^{27}$ Many questions arise when 
trying to define the form of audiences: does the securitizing agent chooses the audience that he speaks for? Does the audience is created or only appears after the speech-act is externalized? Are audiences just passive or are they important nodes of the "network of securitization"? These questions show how the definition of the audience is a delicate step in empirical research in ST studies.

It is particularly interesting how the theme of audiences appears in Arendt's essay Lying in Politics. In this text, one of the best examples of Arendt's "engaged" writings, she delves into the Pentagon Papers used by the US administration to justify the American intervention in Vietnam, thus drawing the conclusion that those documents were a deliberate attempt to manipulate public opinion and the Congress in order to legitimize an invasion of the Southeast country. In order to achieve this goal, Arendt argues that the Pentagon Papers showed a defactualized version of the reality, carefully orchestrated by the:

Problem-solvers who indefatigably prepared their scenarios for 'relevant audiences' in order to change their states of mind - 'the communists (who must feel strong pressures), the South Vietnamese (whose morale must be buoyed, our allies (who must trust us as 'underwriters') and the US public (which must support the risk-taking with US lives and prestige' $(1972,19)$.

In Lying in Politics, Arendt recurrently uses the concept of audiences, constructing a powerful critique of how the 'support' for the war was built by a network of official speeches, policy papers, official documents and media images. Throughout the text, these contextual audiences emerge through the connection established between actor and spectator after the utterance of a speech act. The audience is thus perceived as an active actor within the securitization process as it shapes securitizing actor's speech act before and after the utterance - their co-constitution is therefore apparent. In her words, "the liar [or the actor per se] has the great advantage of knowing beforehand what the audience wishes or expects to hear" $(1972,6)$. In the writings of Lying in Politics, Arendt presents a tangible idea of audience.

From this text, we can extract some important insights of how audiences behave and what constitute them. Here, Arendt works the idea of how the Pentagon actively pursued to convince the Congress and the President, plus winning "the minds of people" in order to invade Vietnam. According to her:

(...) lying statements consistently violated the astoundingly accurate factual reports of the intelligence community (...). The crucial 
point here is not that the policy of lying was hardly ever aimed to the enemy (...), but was destined chiefly, if not exclusively, for domestic consumption, for propaganda at home, and especially for the purpose of deceiving Congress $(1972,14)$

Along with the consideration of an internal audience as more important than the enemy itself, Arendt presents another thoughtful insight about the audience - the President, a purportedly strong agent within the decision-making process and, therefore, an allegedly securitizing actor, is also considered to be part of an audience. In what we might call her "case study" of the Vietnam War, the President of the US was "oddly enough, the only person likely to be an ideal victim of complete manipulation" $(1972,9)$. Here, there is no beforehand inference of acting political men or states to be necessarily securitizing actors and democratic national or international decision-making spheres to play the audience role.

Her essay is interesting as it defines the interplay role that bureaucratic agencies have in democratic societies. They are, at the same time, a self-referent audience empowered by their domination of scientific arguments and domination of "facts" (B)" (Berling 2011) that use "the modern arsenal of political theory [and science] - the game theories and system analyses, the scenarios written for imagined audiences" in order to force these audiences into "mutually exclusive dilemmas" (Arendt 1972, 12). Many recent authors have emphasized the role of these technical elites $^{28}$ (Cavelty 2014) and their role as "risk managers" (Aradau et al. 2008) creating a political field based technicalities. They are thus empowered by their "knowledge" while they swiftly gain leverage against those audiences that contest the securitization move, but do not possess the same "credentials" that these professionals do. As Arendt competently shows in Lying in Politics shows, theses empowered agents are rapidly increasing in a world concerned with the daily management of risk, causing the slowly reduction of the public sphere vis-à-vis the increasing domain of the arcana imperii that remove political issues out of the deliberative and open arena of democratic policies into the realm of secrecy and professional management.

What is particularly interesting in her argument in Lying in Politics is how the Pentagon bureaucracy is viewed, to put it in the jargon of ST, in terms of a securitizing actor and an audience simultaneously. Like Stritzel (2007, 363) pointed out, speaker-audience relations are a complex feature in the theory and most of the times it is not easy or not even possible to "figure out clearly which is audience is, when and why". He shows that the positional power of actors matter, but also their embeddedness in existing discourses is crucial to understand the complexity of the network of 
speech-acts. In a similar fashion, Arendt curiously argue that the Pentagon Papers were so deceitful, that the general public in the US had a clearer picture of the situation in the Vietnam than the bureaucrats in Washington.

The problem has been formulated in a similar way by Balzacq (2011) which distinguished called empowered audiences from the general public or what Huysmans (2006) saw as the conflict and articulation between elite and public discourse in the formulation of policies and decisions. The problem of audiences, added the problem of how public opinion can be influenced by mass media visual representations of risk, fear and violence (Hansen 2011), it may seem that individuals are absolutely powerless when confronted with the "reality" of security problems. But to assume that audiences are simple "silent majorities" who are supposed to watch the scenarists' productions" (Arendt 1972, 35) is to simply deny agency to a wide range of actors that strand out of the decision-making circle. Academia, whistle-blowers, dissident decision-makers, and, more importantly, the "victims" of securitization, among a wide range of possible audiences and "othernesses", there would be simple recipients of political orders and political control. Thus, there would be no way-out of securitization.

Besides her contribution to the audience's theme, in Lying in Politics Arendt's also contests what could be the ultimate aim of a securitizing movement. In her 'case-study' about the Vietnam War, she affirmed that the US objective was "neither power nor profit" $(1972,17)$ (nor survival if we recall the Schmittian influence in ST) but rather the mere maintenance of its image of omnipotence and worldwide position of leadership. ${ }^{30}$ Arendt opens, therefore, the logic of a security speech-act that can be used as a means to divergent ends not necessarily related to the friend/enemy survival mode of politics - interests of any kind can be made into a security utterance in order to invoke audience's attention that shows that securitization is not only a distinction between friend and foe, but a much more subtle theory that tries to unveil the complex dynamic of contemporary security discourses.

\section{FINAL REMARKS}

In this article we have suggested that even though Carl Schmitt presents some contributions to ST's framework, his concept of the political actually cripples some of the theories potentials to explain the formation of security discourses (especially desecuritization) and, most importantly, affects the core normative proposition of the theory. On the other hand, Hannah Arendt can enhance both propositions. This is not something new, but that has been on the foundation of the theory although without 
proper theoretical development. An Arendtian conception of politics and speech-act lies at the core of the theory and is, thus, an essential part to understand the theory's concepts and potentials.

The co-existence of speech and actor as the core essence of political life for Arendt is one of her central ideas used here to strengthen securitization theory's framework and privileges the idea of a perlocutionary speech act (with its intersubjective content) over a illocutionary act. By establishing these to variables as fundamentally indissociable ones, Arendt eliminates the former precedence of a securitizing utterance over the audience. This co-constitution and equality in importance and emphasis is extremely desired if one wants to assure ST's sociological character. Plus, through the theory of judgment researches can be commenced from a desecuritization perspective and thus provide necessary encouragement for emancipation studies. These two notions add up to the theory's quest to understand causality in the security field, while also maintaining a critical approach (a "responsibility" which is a deliberate political choice) (Wæver 2014).

This paper briefly explored some of Arendt's concept that seem undeveloped in the ST despite her "silent presence" in the theory from its very beginning. As remarked in the beginning of the text, this is just one of the possible interpretations that Arendt offers to deal with the contemporary problems of modern politics. And although Arendt is present in the theory, it is necessary to better assess how her concepts may work to advance empirical questions that stem from Securitization Theory contradictions and ambiguities.

\section{REFERENCES}

Agamben, G. 1998. Homo Sacer: Sovereign Power and Bare Life. Standford: Meridian.

Aradau, C. 2004. Security and the democratic scene: desecuritization and emancipation. Journal of International Relations and Development, 7:388-413.

2014. The promise of security: resilence, surprise and epistemic politics. Resilence: International Policies, Practices and Discourses, 2 (2): 1-15.

Aradau, C., Lobo-Guerrero, L., Van Munster, R. 2008. Security, Technologies of Risk, and the Political: Guest Editors' Introduction. Security Dialogue, 39: 147-154.

Arednt, H. 1958. The Human Condition. Chicago: University of Chicago Press, 1958. 
1961. Between Past and Future: Six Exercises in Political Thought. New York: The Viking Press.

1970. On Violence. New York: Harcourt, Brace \& World.

1972. Crises of the Republic. New York: Harcourt Brace Jovanovich.

1973. The Origins of Totalitarianism. New York: Harcourt Brace.

1978. Thinking and Moral Considerations: A Lecture. Social Research, 38

(3): 417-446.

1990. On Revolution. New York: Penguin Books.

. Lectures on Kant's Political Philosophy. 1992. Chicago: University of Chicago Press. Prefácio de Ronald Beiner.

Austin, J. 1962. How to do things with words. Oxford: Claredon Press.

Balzacq, T. (Org.). 2011. Securitization Theory: How security problems emerge and dissolve. New York: Routledge.

2014. The 'Essence' of securitization: theory, ideal type, and a sociological science of security. In: Balzacq, T. et. al. Forum: What kind of theory - if any - is securitization? Online, Available at: <http://goo.gl/h2ovUE > Access: 04 Feb. 2015.

Benhabib, S. 2000. The Reluctant Modernism of Hannah Arendt. Oxford: Rowman \& Littlefield.

Behnke, A. 2006. No Way Out: Desecuritization, Emancipation and the EternalReturn of the Political - A Reply to Aradau. Journal of International Relations and Development, 9 (1): 62-69.

Berling, T. 2011. Science and Securitization: Objectivation, the authority of the speaker and mobilization of scientific facts. Security Dialogue, 42 (4-5): 385-397.

Bigo, D. 2002. Security and Immigration: Toward a Critique of the Governmentality of Unease. Alternatives, 27: 63-92.

Buzan, B. 2009. Macrosecuritisation and security constellations: reconsidering scale in securitization theory. Review of International Studies, 35: 253-276.

Buzan, B., Weaver, O. 2009. Macrosecuritisation and security constellations: 
reconsidering scale in securitisation theory. Review of International Studies, 35: 253-276.

Buzan, B., Weaver, O., Wilde, J. de. 1998. Security: A New Framework for Analysis. Boulder and London: Lynne Rienner Publishers.

Canovan, M. 1978. The Contradictions of Hannah Arendt's Political Thought. Political Theory, 6 (1).

1992. Hannah Arendt: a Reinterpretation of Her Political Thought. Cambridge: Cambridge University Press.

Cavelty, M. 2014. Breaking the Cyber-Security Dilemma: Aligning security needs and remote vulnerabilities. Science and Engineering Ethics, 20 (3): 701-715.

Chandler, D. 2008. The Revival of Carl Schmitt in International Relations: The Last Refuge of Critical Theorists? Millenium Journal of International Studies, 27 (1): 27-48.

Ciuta, F. 2010. Conceptual Notes on Energy Security: Total or Banal Security? Security Dialogue, 41 (2): 123-144.

D'Entrèves, M. 2014. "Hannah Arendt”. The Stanford Encyclopedia of Philosophy. Available at: < http://goo.gl/mOzauK>. Access: 02 Feb. 2015. . 1994. The Political Philosophy of Hannah Arendt. London: Routledge.

Floyd, R. 2010. Security and the Environment: securitization theory and US environmental security policy. New York: Cambridge University Press.

Gad, U., Petersen, K. 2011. Concepts of Politics in Securitization Studies. Security Dialogue, 42 (4-5): 315-328.

Guzzini, S. 2011. Securitization as a causal mechanism. Security Dialogue, 42 (4-5): 329-341.

Habermas, J. 1977. Hannah Arendt's Communications Concept of Power. Social Research, 44 (1): 3-24.

Hansen, L. 2008. Visual Securitization: Taking Discourse Analysis from the Word to the Image. 49th International Studies Convention, San Francisco.

. 2012. Reconstructing desecuritization: the normative-political in the Copenhagen School and directions for how to apply it. Review of International Studies, 38 (3): 525-546. 
Huysmans, J. 1998. The question of the Limit: Desecuritisation and the Aesthetics of horror in Political Realism. Millenium Journal of International Studies, 27 (3): 569-589.

. 1999. Know Your Schmitt: a godfather of truth and the spectre of Nazism. Review of International Studies, 25 (2): 323-328.

2006. International Politics of Insecurity: Normativity, Inwardness and the Excpetion. Security Dialogue, 37 (11): 11-29.

. 2008. The Jargon of Exception - On Schmitt, Agamben and the Absence of Political Society. International Political Sociology, 2: 165-183.

2011. What's in an Act? On security speech acts and little security nothings. Security Dialogue, 42: 371-385.

Isaac, J. 1994. Oases in the Desert: Hannah Arendt on Democratic Politics. American Political Science Review, 88 (1): 156-168.

Jutila, M. 2006. Desecuritizing Minority Rights: Against Determinism. Security Dialogue, 37 (2): 167-185.

Klusmeyer, D. 2011. The American Republic, Executive Power and the National Security State: Hannah Arendt's and Hans Morgenthau's Critiques of the Vietnam War. Journal of International Political Theory, 7 (1): 63-94.

Léonard, S., Kaunert, C. 2011. Reconceptualizing the audience in securitization theory. In: Balzacq, T. (Org.). Securitization Theory: How security problems emerge and dissolve. New York: Routledge, 58-76.

Mouffe, C. 1993. The Return of the Political. New York: Verso.

Mrovlje, M. 2014. Narrating and understanding. In: Hayden, P. Hannah Arendt: Key Concepts. London: Routledge.

Roe, P. 2008. Actor, Audience(s) and Emergency Measures: Securitization and the UK's decision to Invade Iraq. Security Dialogue, 39 (6): 615-635.

2012. Is securitization a negative concept? Revisiting the normative debate over normal versus extraordinary politics. Security Dialoge, 43 (3): 249-266.

Salter, M. 2008. Securitization and desecuritization: a dramaturgical analysis of the Canadian air Transport Security Authority. Journal of International and Development, 11:321-349. 
2011. When Securitization fails: the hard case of counter-terrorism programs. In: Balzacq, Thierry (Org.). Securitization Theory: How security problems emerge and dissolve. New York: Routledge, 116-132.

Schmitt, C. 2007. The concept of the political. Chicago: The University of Chicago Press.

Stritzel, H. 2011 . Security, the translation. Security Dialogue, 42 (4-5): 343-355.

Towards a Theory of Securitization: Copenhagen and Beyond. European Journal of International Relations, 13 (3): 357-383.

Teles, E. 2013. Ação Política em Hannah Arendt. São Paulo: Discurso Editorial, 2013.

Tjalve, V. 2011 . Designing (de)security: European exceptionalism, Atlantic republicanism and the 'public sphere'. Security Dialogue, 42 (4-5): 441-452.

Villa, D. Hannah Arendt: modernity, alienation and critique. In: Calhoun, C., McGowan, J. (Org.). 1997. Hannah Arendt and the Meaning of Politics. Minneapolis: University of Minnesota Press.

Voice, P. 2014. Labour, work and action. In: Hayden, P. Hannah Arendt: Key Concepts. London: Routledge, 36-51.

Vuori, J. 2011. How to do Security with Words: A Grammar of Securitisation in the People's Republic of China. University of Turku.

2008. Illocutionary Logic and the Strands of Securitization: applying the Theory of Securitization to the Study of Non-democratic Political Orders. European Journal of International Relations, 14 (1): 65-99.

Wæver, O., Greenwood, M. 2013. Copenhagen-Cairo on a roundtrip: A security theory meets the revolution. Security Dialogue, 44 (4-5): 485-506.

Wæver, Ole. 1998. Securitization and Desecuritization. In: Lipschutz, R. On Security. New York: Columbia University Press.

. 2004. The Ten Works. Tidsskriftet Politik, 7 (4).

2011. Politics, security, theory. Security Dialogue, 42 (4-5): 465-480.

2014. The Theory Act: Responsibility and exactitude as seen from securitization. In: Balzacq, T. et. al. Forum: What kind of theory - if any - is securitization? Online. Available at: <http://goo.gl/h2ovUE> . Access: 04 Feb. 2015. 
Williams, M. 2003. Words, Images, Enemies: Securitization and International Politics. International Studies Quaterly, 47: 511-531.

Wilkinson, C. 2001. The limits of spoken words: form meta-narratives to experiences of security. In: Balzacq, T. (Org.). Securitization Theory: How security problems emerge and dissolve. New York: Routledge, 94-115.

Willis, S. 2005. Portents of the Real: a Primer for post 9/11 America. New York: Verso. 


\section{NOTES}

1. This paper is located in one of the three debates that Waever proposes to systematize the current state-of-the-art in securitization studies: the "political securitization practices", the politics of securitization theory" and "the political in securitization analysis". We will focus on this third element, trying to understand how Hannah Arendt can help to enhance our understanding of the basic assumptions found explicitly and implicitly on securitization theory.

2. As this paper deals mainly with metatheoritical questions and tries to establish a position on the current debate over the content of the political, a previous warning may be necessary. This article obviously advocates for an Arendtian concept of politics instead of a Schmittian one. This should not be read, however, as if these two authors represent the good and the bad, respectively, as part of the specialized bibliography seems to do. This misperception may be influenced by the roles that both these great writers had on the affairs of their times. In order to fully understand their views of the world, one cannot dissociate an author from its personal experience. However, that does not mean that one should discard the whole content of this or that thinker based solely on their deeds. As Huysmans warned (1999), every time that Schmitt is invoked, it is inevitable that his legacy as the Kronjurist of the Nazi regime will come forward. Although we believe that Schmitt's biography is important to understand the context that influenced his theory (especially his predilection to exceptionalism as the instrument of sovereignty), this should not automatically delegitimize the richness of his thought. The same goes for Hannah Arendt, but in a different fashion. Arendt occupies a more "comfortable" position amongst public opinion and scholarship, especially because of her works on totalitarianism and the famous and provocative text of Eichmann in Jerusulem. Yet, as Villa (1997) correctly pointed out, the thought of Hannah Arendt has also been subject to an intense dispute over its significance. For example, while many see Arendt as a democracy champion - like Habermas (1977) or Benhabib (2000) -, some scholars read her ideas as elitist, exaggeratedly liberal, or, more surprisingly, as antidemocratic (see Isaac 1994; and Arendt 1990, 272-281). Therefore, when dealing with these authors, many (re)interpretations are possible. What we will try to do is to analyze both contributions bearing in mind their usefulness and academic value to explain the elements in Securitization Theory. 
3. Of these authors, Huysmans is the one who dedicated the most effort to understand the problem of Schmitt's exceptionalism. While acknowledging some resemblance between ST and Schmitt's writings, Huysmans also showed the potential flaws and problems with that concept. In his texts, he pointed out that $(2011,381)$ "conceptions of the political based on the paradox of the act should not be simply reduced to a Schmittian-inspired conception of sovereignty".

4. Even Williams (2003,515) was careful enough to warn that Securitization Theory is not "wholly Schmittian", the subsequent debate has many times turned to Schmitt as the cornerstone of the theory.

5. Not many authors have tackled what the exceptional state is or what would be the performative effects of the exception. The concept seems to be embedded in a juridico-institutional tradition of reading sovereignty as the paradox of being inside and outside the juridical order at the same time (see Agamben, 1998, Chapter 1). But one should ask "What do claims of exceptionality do politically?" (Huysmans 2006). We believe that one possible answer for this questions is that exceptionality occurs when an audience accepts to give up something (like their freedom of speech or freedom of movement) in exchange for "more" security. Therefore, the exceptional move requires a trade-off between the audience and the securitization actor. One good example of this concept is the long-debated Patriot Act, approved after 9/11, which tolled constitutional rights of the American audience (although that did not give the US President unlimited powers in a Schmittian fashion). The concept of exceptionality, therefore, is contextual just as the speech-act is. One interesting feature of this idea is how an audience desire for "more" security can impact on the liberties and rights of other collectivities like recent works on the securitization of immigration, securitization of cyberspace or the securitization of the environment demonstrate.

6. In other words, this turns securitization a routinized practice and a policy toolbox for security affairs, rather than a critical concept to deconstruct security discourses.

7. See also Roe (2012) for a more acute theoretical debate on the limits of exceptionalism in Securitization Theory, and Ciuta (2010) for an empirical example about the "constant presence" of security issues instead of "intransient essence of security" affairs.

8. The argument here follows a close relationship of the diagnosis portrayed by Giorgio Agamben (1998) on how the state of exception is turned into the rule of government in modern societies. His perception on this issue is based in a mixed conceptualization that draws from 
Schmitt, Arendt and Foucault. He explicitly relies on Arendt, who, according to him, foresaw how totalitarian regimes turned exception into normal politics. Indeed, in one the most interesting passages in The Origins of Totalitarianism (1963), Arendt confronts this problem: "Raison d'état appeals - rightly or wrongly, as the case may be - to necessity, and the state crimes committed in its name [...] are considered emergency measures, concessions made to the stringencies of Realpolitik, in order to preserve power and thus assure the continuance of the existing legal order as a whole. In a normal political and legal system, such crimes occur as an exception to the rule and are not subject to legal penalty [...] because the existence of the state itself is at stake, and no outside political entity has the right to deny a state its existence or prescribe how it is to preserve it. However - as we may have learned from the history of Jewish policy in the Third Reich - in a state founded upon criminal principles, the situation is reversed. Then a non-criminal act (such as, for example, Himmler's order in the late summer of 1944 to halt the deportation of Jews) becomes a concession to necessity imposed by reality, in this case the impending defeat. [...] Can we apply the same principle that is applied to a governmental apparatus in which crime and violence are exceptions and borderline cases to a political order in which crime is legal and the rule?"

9. 'As Guzzini pointed out (2011,335): "it is not a generic friend-foe distinction but embedded self-other understandings that predispose political discourses, public opinion and hence also the receptivity of the wider public to certain political moves". In other words, securitization cannot be regarded simply as the utterance of the sovereign.

10. This distinction comes from Austin's (1962, 101) perception of the three types of acts within a speech act: the locutionary act is the utterance of an enunciate that have a given sense and reference, as expressed in the sentence "he said to me to "shoot her"'; the illocutionary act is also the utterance of an enunciate with a given sense and reference, but it contains a performative force, as presented in the sentence "he urged (or advised, ordered, etc) me to shoot her"; the perlocutionary act is a utterance of an enunciate with performative sense and force and, especially, the type of act that shows the concrete inner effects of this same utterance, as we can identify in the sentence "he persuaded me to shoot her" (Austin 1962, 101). From Austin's perspective, the three types in combination forms the total meaning of a speech act.

11. It is important to add there has been a growing debate between the illocutionary or perlocutionary character of the speech-act. Wæver (2014) has defended that the theory is based on the idea of illocu- 
tionary act that draws not from Austin, but from Searle's work. He argues that by separating action and speech, Austin's description of the speech-act cannot satisfy the ontological premises of the theory. He defends, therefore, a different conceptualization of the illocutionary act, claiming that it is the only way that the ST can sustain itself as a theory that allows for systematic investigation of social mechanisms of the securitization process. On the other side of the debate, Balzacq (2011, 2014) emphasizes how the perlocutionary act allows for a more sociological approach to the problem of securitization, drawing from a Weberian perspective of human agency. This recent debate shows that they may be more than one theory of securitization, with different ways of theorizing and operating different types of methodologies. In this case, we tend to agree with the position that ST needs a sociological approach and that the original proposition of Hannah Arendt's philosophy embedded in the theory favors a reading of the speech-act as a perlocutionary one.

12. As Aradau (2004, 392) stresses, securitization therefore leads to a "disruption - or indeed complete abandonment - of open and accountable government. In other words, securitization is bad for democracy". It should also be noted that Hannah Arendt, in her last years, made continuous references to what she called an excessive empowerment of the Executive branch in the United States by the constant use of the "national security" discourse and how it undermined the republican vocation of the country. For a comprehensive reading on this subject, see Klusmeyer, 2011.

13. Vuori (2008) makes a similar argument about the illocutionary character of securitization process in authoritarian governments.

14. In Aradau's (2004; 2008) work on security and emancipation, her main critique to this Schmittian notion of the political in securitization is that its exclusionary character divides the political community between those who can belong to it and those who cannot. What strucks us, and possibly other readers of securitization theory, is how Schmitt has been used by a wide range of post-structuralist and critical studies. As Chandler (2008) points out, much of this revival of Schmitt in international relations is about the crisis of critical theorizing than the relevance of Schmitt per se. While we acknowledge the importance of Schmitt's work, we argue that Schmitt is (and cannot be) the answer for the flaws in Securitization Theory.

15. Or, as Gad and Petersen (2011,320) point out: "Rather, it is the Copenhagen School's concept of security that resembles Schmitt's concept of politics" 
16. For a good conceptualization on how desecuritization might work, see Hansen, 2012 and what she characterizes as four typologies of desecuritization: stabilization, replacement, reticulation and silencing.

17. Or why it cannot. See Stritzel (2011) for a critic about the "performative" character of Arendt's theory of action applied to ST.

18. For example, Buzan et al. (1998) only say that the original idea of the theory is located somewhere between concept of politics of Hannah Arendt and David Easton.

19. As a way of reconquering the agency of individuals in the public realm, thus removing security of the secluded realm of military affairs.

20. There are many interesting critics about Arendt's concept of the political. Among the most interesting, see Habermas (1977) who criticizes her for not grasping problems of structural power or Canovan (1978 apud D'Entrèves 1994) who sees Arendt's rejection of representative democracy (in favor of a system of councils) as "wildly utopian".

21. Arendt's formation on classical philosophy and her unorthodox scholarship reinforce that idea.

22. "The labor of our bodies and the work of our hands" (Arendt 1959, 79).

23. An idea that she explicitly draws from Aristotle who characterized man as a political being endowed with speech (Arendt 1990, 19).

24. Arendt makes further differentiation of what would be an "ideal" type of judgement, one based in the agreement of others through persuasion and justification arising from a critical exam of the context (Hayden 2014). Here, Arendt's considerations are very similar to Habermas' theory of communicative action as both authors are driven by the paradoxes of modernity.

25. For Arendt, opinion is a distinctive element of political life and should not be mistaken with common sense. For her, there is an antagonism "between rational truth and well-grounded opinion, since the former does not allow for debate and dissent, while the latter thrives on it. Arendt's defense of opinion must therefore be understood as a defense of political deliberation, and of the role that persuasion and dissuasion play in all matters affecting the political community. Against Plato and Hobbes, who denigrated the role of opinion in political matters, Arendt reasserts the value and importance of political discourse, of deliberation and persuasion, and thus of a politics that acknowledges difference and the plurality of opinions" (D'Entrèves 2014). It is curious how for Arendt the presentation of blunt facts can actually work as a way to impose an opinion. This can be seen in the field of security in the light of a groundbreaking event that is presented as an undeniable threat or insecurity (for example, the recurring images of the 
falling Twin Towers). For an interesting essay on how "real" facts influence the construction of discourses see Willis, 2005.

26. Arendt herself distrusted public opinion in an age of mass media and "spectacle". She stressed that valid opinions could only arise from the debate among individuals which should have access to unbiased information. Only by confronting different points of views it that an opinion could be informed. This tension persists stronger than ever especially by the daily bombardment of images, polls, surveys that try to conquer and direct public opinion emotions and reason.

27. An illustrative example of this trend is the numerous works about the securitization of terrorism after $9 / 11$. Some of them focusing on deliberative instances in the US and the Security Council (Motta 2014) or other national parliaments outside the US, some focusing on the reaction of the public opinion, or other works focusing on the reactions of defense and security agencies on the subject (Salter 2011).

28. "Shared techniques [...] translating qualities and contents into quantities and numbers with which calculate outcomes" (Arendt 1972, 36).

29. Also see Salter, 2008 and his differentiation of popular, elite, technocratic and scientific audiences.

30. Vietnam War is not the sole example of non-security issues turned into a securitization utterance logic. Iraq intervention in 2003 , for instance, was also manipulated as a question of survival. 


\section{RESUMO}

Nos últimos anos, muitos estudiosos interessados na Escola de Copenhague (EC) viraram-se para os trabalhos do cientista político alemão Carl Schmitt, a fim de fortalecer os fundamentos filosóficos da teoria, especialmente o conceito disputado de exceção. Schmitt é uma contribuição singular e importante para o debate; no entanto, a sua definição da política traz um conceito de securitização mais conservador e unilateral, como a política só fosse explícita em momentos de exceção. Nossa idéia neste breve artigo é apresentar uma contribuição para essa discussão vinda de uma perspectiva menos considerada: as obras e os escritos de Hannah Arendt. Vamos examinar como suas idéias para a política e a exceção podem lançar uma luz sobre as mesmas questões que Schmitt parece ser impreciso. Acreditamos que trazer Hannah Arendt para o debate oferece uma compreensão diferente dos problemas fundamentais do conceito de securitização e aumenta o apelo normativo da teoria para uma base mais ampla e mais sofisticada, abrindo novos caminhos para a pesquisa e discussão no âmbito do quadro da Escola de Copenhague.

Palavras-chave: Teoria das Relações Internacionais; Securitização; Estudos Críticos de Segurança; Hannah Arendt.

\section{ABSTRACT}

In the past few years, many scholars keen to the Copenhagen School (CS) turned to the works of the German political scientist Carl Schmitt in order to strengthen the philosophical foundations of the theory, especially the disputed concept of exception. Schmitt is a singular and important contribution to the debate, however his definition of the political makes securitization concept more conservative and a more unilateral event as politics would only be explicit in the exception spectrum. Our idea in this brief paper is to present a contribution to this discussion coming from a less considered perspective: the works and writings of Hannah Arendt. We will examine how her ideas towards politics and the exception can shed a light on the same issues that Schmitt seems to blur even further. We believe that bringing Hannah Arendt to the debate offers a different understanding of the foundational problems of the securitization concept and enhances the normative appeal of the theory towards a broader and more sophisticated base, opening new paths for research and discussion under the framework of the Copenhagen School.

Keywords: International Relations Theory; Securitization Theory; Critical Security Studies; Hannah Arendt.

Recebido em: 10/05/2016. Aceito para publicação em 10/06/2016. 